\title{
A brief history of scientific ocean drilling programs / Breve história dos programas científicos
}

\author{
Michael Passow \\ Professor de Ciências na Dwight Morrow High School, Englewood, New \\ Jersey, USA. Diretor das Oficinas Earth2Class para Professores, do Lamont- \\ Doherty Earth Observatory da Univ. Columbia e ex-Presidente da National \\ Earth Science Teachers Association. Englewood, NJ 07631. \\ michael@earth2class.org \\ Hélder Pereira \\ Professor de Biologia e Geologia na Escola Secundária de Loulé, Portugal. \\ Participante de duas expedições IODP a bordo do JOIDES Resolution. \\ Leslie Peart \\ Diretora de Educação na Deep Earth Academy, o programa educacional do \\ Consortium for Ocean Leadership. Organizou os programas School of Rock, e \\ desenvolveu recursos online para estudantes e professores.
}

\begin{abstract}
A BRIEF HISTORY OF SCIENTIFIC OCEAN DRILLING PROGRAMS. Brazil recently joined the Integrated Ocean Drilling Program, which conducts scientific expeditions around the world. The Brazilian scientists participated in exploration of deep-sea trenches off Costa Rica. Scientific ocean drilling was first proposed in 1957 and began in the 1960s. In 1968, during only its third Leg (expedition), the "Glomar Challenger" retrieved samples of rocks and sediments from the two sides of the Mid-Ocean Ridge in the South Atlantic, and proved that the sea floors were spreading apart. Before this ability to penetrate deep into the ocean bottom, scientists had collected piston cores. The microfossils in these cores revealed much about Earth's changing climate in the last few million years. Current expeditions by the "JOIDES Resolution," "Chikyu," and mission-specific drilling vessels add to the already impressive and extensive understanding of our planet's geological history uncovered through ocean drilling. In recent years, educators have accompanied the scientists during expeditions, and created many learning activities and outreach materials for students and the general public. Citation: Passow M., Pereira H., Peart L. 2013. A Brief history of scientific ocean drilling programs. Breve história dos programas científicos de perfuração oceânica. Terræ Didatica, 9(2):65-73. <http://www.ige.unicamp.br/terraedidatica/>.
\end{abstract}

KEYWORDS: Ocean drilling, teacher professional development, research at sea.

RESUMO Recentemente, o Brasil aderiu ao Integrated Ocean Drilling Program, que realiza expedições científicas em todo o mundo. Isso permitiu que cientistas brasileiros pudessem participar na exploração do fundo do oceano nas imediações de uma fossa oceânica ao largo da Costa Rica. A perfuração do fundo do oceano para fins científicos foi proposta pela primeira vez em 1957 e começou na década de 60 do século XX. Em 1968, naquela que foi apenas a sua terceira expedição, o "Glomar Challenger" recuperou amostras de rochas e sedimentos dos dois lados da dorsal média-oceânica no Atlântico Sul, e revelou a expansão dos fundos oceânicos. Antes da capacidade de perfurar o fundo do oceano a grandes profundidades, os cientistas apenas tinham à sua disposição testemunhos obtidos com amostradores de tipo "pistão". Os microfósseis obtidos a partir desses testemunhos têm permitido fazer muitas descobertas sobre as oscilações climáticas da Terra. Nas expedições realizadas atualmente pelo "JOIDES Resolution", pelo "Chikyu”, e pelas plataformas de perfuração das missões específicas, continuam a surgir descobertas impressionantes que têm contribuído para melhorar a compreensão da história geológica do nosso planeta. Nos últimos anos, vários educadores têm acompanhado os cientistas durante as expedições, e criaram vários materiais educativos e de divulgação destinadas a estudantes e ao público em geral.

PALAVRAS-CHAVES: Perfuração oceânica, formação profissional de professores, pesquisa no mar. 


\section{Introduction}

During the summer of 2012, Brazil officially became the $26^{\text {th }}$ member of the Integrated Ocean Drilling Program (http://www.oceanleadership. org/2012/brazil-joins-international-marine-research-effort/). In the fall, Brazilian scientists participated in the Costa Rica Seismogenesis Project (http://joidesresolution.org/node/2677). Together with scientists from many other countries aboard the drilling ship JOIDES Resolution (JR) (Fig. 1), they spent six weeks investigating an erosional subduction zone where Earth's crust returns to the mantle at an undersea trench.

This expedition belongs to the long and illustrious history of scientific discoveries accomplished through ocean floor drilling. The idea of drilling through the oceanic crust to obtain samples of the mantle was first proposed in 1957 by Walter Munk of the Scripps Institution of Oceanography, during the International Geophysical Year (http://www. nas.edu/history/mohole/). "Project Mohole," as the program was called, demonstrated the feasibility of deep ocean drilling. But it was cancelled in 1966 by the U.S. Congress when costs became too high.

Yet the dream of drilling into the sea floor to make important discoveries was kept alive through the Deep Sea Drilling Project (DSDP). The National Science Foundation (NSF) supported efforts by Scripps Institution of Oceanography and others to construct a special drilling ship http://www. deepseadrilling.org/about.htm). Glomar Marine Company began building the Glomar Challenger in 1967. This name honored the HMS Challenger, the first oceanographic research vessel to circumnavigate the globe in $1872-1876$.

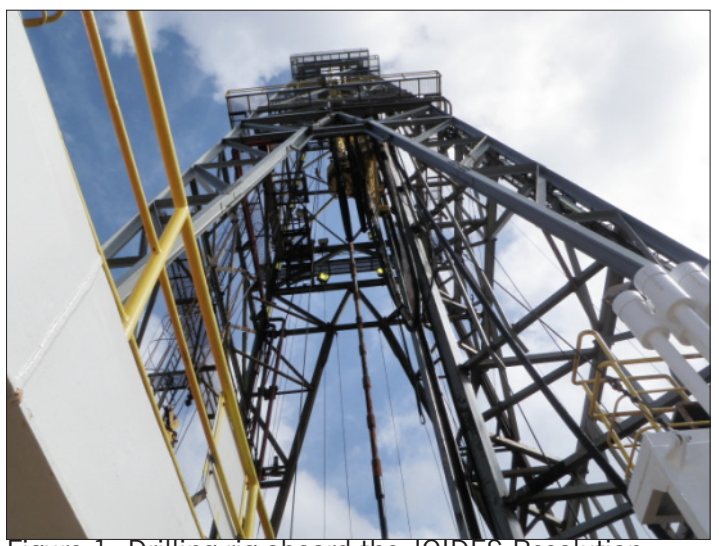

Figure 1. Drilling rig aboard the JOIDES Resolution.

Figura 1. Torre de perfuração a bordo do navio JOIDES Resolution.

\section{Introdução}

Durante o verão de 2012, o Brasil tornou-se oficialmente o $26 .^{\circ}$ membro do Integrated Ocean Drilling Program (http://www.oceanleadership.org/2012/brazil-joins-international-marine-research-effort/). No outono seguinte, cientistas brasileiros participaram na Expedição 344: Costa Rica Seismogenesis Project (http://joidesresolution. org/node/2677). Passaram seis semanas a bordo do navio de perfuração JOIDES Resolution (JR) (Fig. 1), juntamente com cientistas de vários países, a investigar uma zona de subdução de tipo erosivo onde a crosta terrestre mergulha em direção ao manto ao longo de uma fossa oceânica.

A expedição consistiu em mais uma etapa da já longa e ilustre história de descobertas científicas efectuadas por intermédio da realização de perfurações oceânicas. A ideia de perfurar a crosta oceânica para obter amostras do manto foi proposta pela primeira vez por Walter Munk, da Scripps Institution of Oceanography (SIO), durante o Ano Geofísico Internacional que transcorreu em 1957. O programa de perfuração oceânica, designado "Projeto Mohole", demonstrou a viabilidade da perfuração em águas profundas. Porém, o programa viria a ser cancelado pelo Congresso dos EUA, em 1966, quando os custos se tornaram excessivos (http://www.nas.edu/ history/mohole/). No entanto, o sonho de perfurar o fundo do mar com o objetivo de fazer descobertas inimagináveis foi mantido vivo por meio do Deep Sea Drilling Project (DSDP). A National Science Foundation (NSF) apoiou os esforços realizados pela SIO e outras instituições para construção de um navio especial. A Glomar Marine, Inc. (agora Transocean) projetou o navio, e a Levingston Shipbuilding Company começou a construir o Glomar Challenger, no Texas, em 1967 (http://www.deepseadrilling.org/ about.htm). O nome do navio pretendia homenagear o HMS Challenger, o primeiro navio de pesquisa oceanográfica a circum-navegar o globo entre 1872 e 1876.

O navio foi entregue à SIO em 1968 e, quase de imediato, foram feitas importantes descobertas. No segundo local de perfuração da segunda campanha (Leg 2) do DSDP, efetuada no Golfo do México, foram encontrados domos salinos dando início à era da exploração de petróleo que por lá continua até hoje. Todavia, os testemunhos de sedimentos recolhidos durante a terceira campanha $(\operatorname{Leg} 3)$ do DSDP, em 10 locais situados em ambos os lados da Dorsal Média-Atlântica a leste do Brasil, revelar-se- 
Scripps accepted delivery of the Glomar Challenger in 1968. Successful discoveries were made almost immediately. Salt domes were found on the Gulf of Mexico floor in Leg 1 Site 2, opening the era of petroleum exploration in that region which continues today. But of inestimable scientific importance, during Leg 3, cores recovered from 10 sites on either side of the Mid-Atlantic Ridge east of Brazil provided definitive evidence confirming sea floor spreading, or as it was called then, "continental drift."

Prior to the Glomar Challenger's (Fig. 2) capability of penetrating deep into the sea floor, the best scientists could do was retrieve "piston cores." These were collected by dropping hollow tubes from research ships. The tubes were usually $9-$ $27 \mathrm{~m}$ long. A heavy weight enabled the tube to force a path through the bottom sediments, and special caps kept the sediments from falling out. When the cores were returned to laboratories, they were carefully examined. From minerals in the sediments, and, more importantly, the microfossils buried among the minerals, scientists made many important discoveries about Earth's history, especially about climate changes.

The Lamont-Doherty Earth Observatory of Columbia University hosts one of the greatest collections of deep sea cores (http://www.ldeo. columbia.edu/core-repository). Dr. Maurice Ewing, founder and first director of the Observatory, began the core collection in 1947 during a scientific cruise aboard the "Atlantis," operated by the Woods Hole Oceanographic Institute. In 1953, "Doc" Ewing arranged to obtain Columbia's first research vessel, the Vema. He established a policy

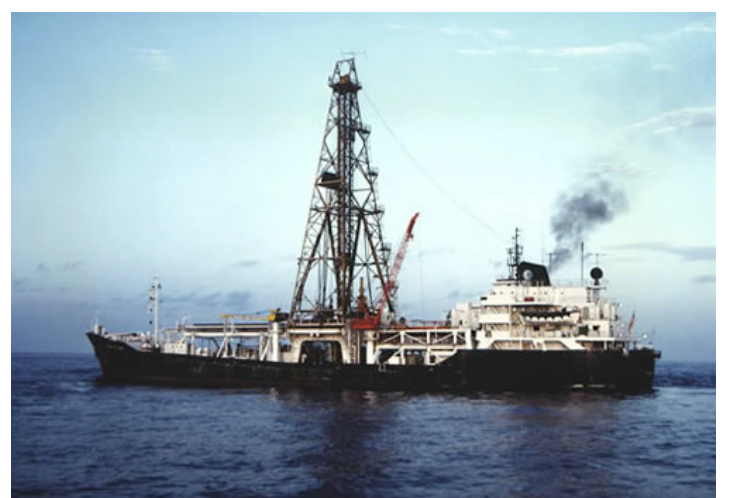

Figure 2. The Glomar Challenger oceanographic vessel. (Source: http://iodp.tamu.edu/publicinfo/glomar challenger.html).

Figura 2. Navio oceanográfico Glomar Challenger. (Fonte: http://iodp.tamu.edu/publicinfo/glomar_challenger. html). -iam de inestimável importância do ponto de vista científico. Os dados obtidos forneceram as provas definitivas que acabariam por confirmar a teoria da expansão do assoalho oceânico.

Antes do Glomar Challenger (Fig. 2), que permitiu iniciar perfuração do fundo do oceano a grandes profundidades, os cientistas apenas tinham à sua disposição testemunhos obtidos com amostradores de tipo "pistão". Os testemunhos eram recolhidos largando-se tubos ocos a partir de navios de pesquisa. Os tubos tinham, de um modo geral, entre 9 e $27 \mathrm{~m}$ de comprimento e, graças a um lastro bastante pesado, penetravam os sedimentos, que eram mantidos no interior do tubo por ação de tampas especiais. Uma vez nos laboratórios, os testemunhos de sedimentos eram cuidadosamente analisados determinando-se várias propriedades, tais como a composição mineralógica. Os microfósseis preservados nos sedimentos marinhos revelar-se-iam bastante importantes, permitindo aos cientistas fazer muitas descobertas relevantes sobre a história da Terra, principalmente sobre as oscilações climáticas.

O Lamont-Doherty Earth Observatory (LDEO), da Universidade de Columbia, abriga uma das maiores colecções de testemunhos de sedimentos e rochas recolhidas no mar profundo (http://www.ldeo. columbia.edu/core-repository). O Dr. Maurice Ewing, fundador e primeiro diretor do LDEO, iniciou a colheita de testemunhos, em 1947, durante um cruzeiro científico, a bordo do navio Atlantis, que era operado pelo Woods Hole Oceanographic Institute. Em 1953, "Doc" Ewing decidiu adquirir o Vema, que seria o primeiro navio de pesquisa do LDEO. Durante os cruzeiros ele definiu a regra de parar o navio ao meio-dia, onde quer que ele estivesse, com o objetivo de recolher "Um testemunho por dia”. A razão para tal procedimento resultava da convicção de Ewing de que poderia não voltar a ser possível regressar àquele local, por isso a parada era fundamental para conseguir recolher todo e qualquer material que pudesse ser recuperado (http:// www.ldeo.columbia.edu/core-repository/about-us/ core-repository-history).

O Vema e o segundo navio de pesquisa operado pelo LDEO, o Robert C. Conrad, foram os primeiros navios de investigação oceanográfica a viajar mais de $1,600,000 \mathrm{~km}$ ao longo do nosso planeta. As descobertas feitas pelos cientistas a bordo destes navios contribuiu significativamente para aumentar nossa compreensão do Sistema Terra. Atualmente, o Lamont-Doherty Core Repository (LDCR), possui 
of stopping at noon wherever the ship was in its cruise to collect "A Core A Day." His reasoning was that it might never be possible to return to that location, so it was imperative to obtain whatever could be retrieved. (http:/www.ldeo.columbia.edu/ core-repository/about-us/core-repository-history)

The Vema and the second research vessel operated by Columbia, the Robert C. Conrad, were the first research vessels to travel more than 1,600,000 $\mathrm{km}$ across our planet. Discoveries made by scientists aboard these ships added significantly to our understanding of the Earth System. Today, the Lamont-Doherty Core Repository more than $72,000 \mathrm{~m}$ of cores, plus thousands of additional samples collected by dredges, submersibles, and other methods. Scientists from around the world come to the Repository to collect samples for their research, request to have materials shipped to them, or use the Repository's data base (http://www.ldeo. columbia.edu/core-repository).

We learned much about the history of Earth's climate change, sea floor mineral resources, and much more from these materials. But piston cores and dredge samples only retrieve materials from the upper few meters of sediments. They cannot reach the thousands of meters of sediments and rocks that lay untouched beneath. To collect samples of these, we must rely on the JOIDES Resolution and other deep-sea drilling ships.

The Deep Sea Drilling Project, as mentioned above, began in 1968 and included 96 Legs (expeditions). Beginning in 1975, scientists from other countries - the Federated Republic of German, Japan, the United Kingdom, the USSR, and France-joined US colleagues aboard the ship and for post-cruise research. By its conclusion in 1983, the DSDP had obtained 19,119 cores that provided 97,056 m of deep-sea material. The deepest came from 1,741 m below the ocean floor (http://www. deepseadrilling.org/about.htm).

The next stage was the Ocean Drilling Program (ODP). With its launch in 1985, the drilling ship JOIDES RESOLUTION provided scientists with much greater capabilities for discovery than had been possible on the Glomar Challenger (http:// $w w w$-odp.tamu.edu/). This vessel 's name combines the original operating consortium, the Joint Oceanographic Institutions for Deep Earth Sampling, and the HMS Resolution, flagship of Captain James Cook during his $18^{\text {th }}$ century explorations of discovery.

The ODP included 110 expeditions, iden- mais de $72.000 \mathrm{~m}$ de testemunhos, e ainda milhares de amostras recolhidas por dragas, submersíveis e outros métodos. Cientistas de todo o mundo visitam o LDCR para colher amostras para sua investigação, enquanto outros solicitam que lhes sejam enviados materiais, ou usam a base de dados do repositório (http://www.ldeo.columbia.edu/core-repository).

Aprendemos muito sobre a história das oscilações do clima da Terra, os recursos minerais existentes no fundo do mar e muito mais, a partir dos testemunhos obtidos com amostradores de tipo "pistão" e das amostras de dragagem. Todavia, esses métodos apenas permitem recuperar os materiais que jazem nos primeiros metros abaixo do fundo do mar; não possibilitam o acesso aos milhares de metros de sedimentos e rochas que estão mais abaixo. Para recolher amostras destes materiais, é necessário utilizar navios como o JOIDES Resolution e outros navios de perfuração de águas profundas.

O DSDP, como foi anteriormente mencionado, começou em 1968 e incluiu 96 Legs (expedições). A partir de 1975, cientistas de outros países - da República Federal da Alemanha, do Japão, do Reino Unido, da União Soviética, e de França - juntaram-se aos seus colegas norte-americanos, tanto em cruzeiros a bordo do JOIDES Resolution como em investigações realizadas em terra após as expedições. Quando da sua conclusão, em 1983, o DSDP permitiu obter 1.119 testemunhos que forneceram 97.056 $\mathrm{m}$ de amostras da crosta oceânica. $\mathrm{O}$ mais profundo foi recolhido $1.741 \mathrm{~m}$ abaixo do fundo do oceano (http://www.deepseadrilling.org/about.htm).

A etapa seguinte consistiu no Ocean Drilling Program (ODP). Com o lançamento em 1985, a maior capacidade de perfuração do navio JOIDES Resolution permitiu que os cientistas pudessem fazer mais descobertas do que o que era possível com o Glomar Challenger (http://www-odp.tamu.edu/). O nome deste navio combina o acrônimo do consórcio operacional original, Joint Oceanographic Institutions for Deep Earth Sampling, e homenageia o HMS Resolution, comandado pelo Capitão James Cook durante suas explorações realizadas no século XVIII.

O ODP consistiu em 110 expedições identificadas como Legs 100-210. Antes da conclusão desta fase, em 2003, centenas de cientistas de mais de 20 nações participaram de cruzeiros oceanográficos multidisciplinares a bordo doJOIDES Resolution. O principal objetivo das expedições consistiu no estudo e na investigação da história geológica, climática e paleontológica da Terra (http://www.odplegacy. org/science_results/highlights.html). 
tified as Legs $100-210$. Hundreds of scientists from more than twenty nations engaged in multidisciplinary cruises to conduct valuable research into Earth's geologic, climatic, and paleontologic history before the conclusion of this phase in 2003. (http://www.odplegacy.org/science_results/ highlights.html).

Currently, scientific ocean drilling continues through an even-wider international program, the Integrated Ocean Drilling Program (IODP, http:// www.iodp.org/). Goals of the IODP are to:

- deploy state-of-the-art ocean drilling technologies as its essential tool of discovery,

- unify the international research community to explore Earth as a system,

- advance future research and discovery through dissemination of data and samples from global archives, and

- provide scientific context for global awareness of geohazards and environmental change (http://www.iodp.org/faq/\#1).

Between 2006 - 2008, the JR underwent a major refit which gave the ship state-of-the-art drilling equipment, better structural features, and many other improvements. Cruises now can house 50 scientists and technicians, along with its $65 \mathrm{crew}$ members. (http://www.oceanleadership.org/programs-and-partnerships/scientific-ocean-drilling/ integrated-ocean-drilling-program/.)

In addition to the $J R$, IODP exploration of the ocean floor has been carried out by the drill ship Chikyu, operated by the Japan Agency for Marine-Earth Science and Technology. Capable of exploring even deeper than can the JR, the Chikyu recently set a new record for reaching a drilling depth of 2,466 $\mathrm{m}$ beneath the seafloor in the northwest Pacific (http://www.jamstec.go.jp/chikyu/ eng/Expedition/exp337.html).

IODP scientific drilling also uses mission-specific-platform vessels capable of exploring locations inaccessible by these two large vessels. These smaller vessels have operated in polar waters and on the continental shelves in waters too shallow for the JR or Chikyu.

The IODP began in 2003 and will conclude later this year or early next year. Then, scientific ocean drilling will continue as the International Ocean Discovery Program (http://www.iodp.org/ new-program). Brazil, Brazilian scientists, and their international colleagues will continue to add
Atualmente, a perfuração científica do oceano continua em um programa internacional ainda mais amplo, o Integrated Ocean Drilling Program (IODP) (http://www.iodp.org/). Os principais objetivos do IODP são:

- implementar tecnologias de perfuração oceânica de última geração,

- unir a comunidade internacional de investigação para explorar a Terra como um sistema,

- contribuir para aperfeiçoar as futuras pesquisas e descobertas através da disseminação de dados e amostras armazenadas nos repositórios, e

- contextualizar cientificamente a compreensão global sobre os riscos geológicos e as alterações ambientais (http://www.iodp.org/about).

Entre 2006 e 2008, o JOIDES Resolution foi submetido a uma grande remodelação que permitiu equipar o navio com tecnologias de perfuração de última geração, melhorar as suas características estruturais, e efetuar muitas outras melhorias. Agora, durante as expedições, o navio pode acomodar 50 cientistas e técnicos, juntamente com os seus 65 tripulantes (http://www.oceanleadership.org/programs-and-partnerships/scientific-ocean-drilling/ integrated-ocean-drilling-program/).

Para além do JOIDES Resolution, a exploração do fundo do mar realizada no âmbito do IODP tem também sido efetuada pelo navio de perfuração Chikyu, operado pela Japan Agency for Marine-Earth Science and Technology. O Chikyu tem a capacidade de perfurar zonas ainda mais profundas do que o $J R$ e recentemente estabeleceu um novo recorde para a perfuração oceânica alcançando 2,466 $\mathrm{m}$ abaixo do fundo do mar no Pacífico noroeste (http://www.jamstec.go.jp/chikyu/eng/Expedition/ exp337.html).

O IODP também usa navios e outras plataformas de perfuração oceânica em missões específicas, executadas pelo European Consortium for Ocean Drilling Research (ECORD), capazes de explorar locais inacessíveis a navios de grande porte. Os navios e plataformas de perfuração de menores dimensões têm trabalhado em águas polares, no Ártico, e nas plataformas continentais com águas pouco profundas para oJR e o Chikyu (http://www. eso.ecord.org/expeditions/msp.php).

O IODP começou em 2003 e terminará este ano ou no início do próximo. A partir de outubro de 2013, com o objetivo de reforçar o enfoque no esforço internacional do programa, a perfuração 
to the legacy of discoveries that date back more than forty-five years.

\section{What Happens During an Ocean Drilling Expedition?}

Each expedition, or Leg, begins with formal proposals by teams of scientists to investigate major scientific questions. Expert panels evaluate all proposals, and those selected begin the process of gathering necessary equipment and waiting until the ship is available. In some cases, there may be several years between when a proposal is approved and the ship will be in the appropriate part of the ocean. Decades of research enables the operations aboard the JR to be both routine and eventfulroutine because the same processes have occurred many times before, and eventful because the scientists and technicians never know what they will actually find during each expedition. (http:// joidesresolution.org/node/2825).

Each expedition aboard the JR usually lasts for two months. Scientists and crews work 12-hour shifts. Sailing to the drilling location, everyone prepares for the round-the-clock activities soon to begin. When the JR reaches the designated site, the drilling crew patiently assembles 10 -meter sections of piping. These are raised by the $62-\mathrm{m}$ high derrick, then lowered to the sea floor in 'strings' that can be over 9,100 $\mathrm{m}$ in length (Fig. 3). Drill bits on the end rotate rapidly to core through sediments and rocks. If all goes well, the cores are then brought back up, retrieved from the pipe, and the process is repeated.

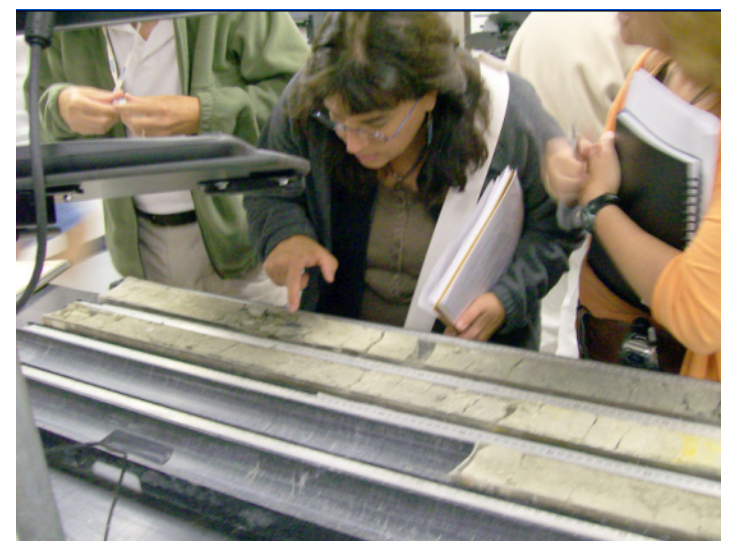

Figure 3. Teachers examining cores archived at the Gulf Coast Repository in College Station, Texas

Figura 3. Professores examinam testemunhos de sondagem armazenados no Repositório da Costa do Golfo em College Station, Texas. científica do oceano continuará sob a designação International Ocean Discovery Program (http://www. iodp.org/new-program). O Brasil, os cientistas brasileiros e os seus colegas da comunidade internacional poderão continuar a acrescentar informações ao legado de descobertas que data de há mais de 45 anos.

\section{0 que acontece durante uma expedição de perfuração científica do oceano?}

Cada expedição começa com a apresentação de propostas formais de investigação, por parte de equipes de cientistas que pretendem estudar questões científicas importantes. As propostas são depois avaliadas por painéis de peritos e as que são seleccionadas, enquanto esperam que o navio esteja disponível, dão início ao processo de coleta dos equipamentos específicos necessários para as análises a efetuar durante a expedição. Em alguns casos, podem decorrer vários anos entre o momento da sua aprovação e o momento em que o navio está disponível para perfurar a zona do oceano definida na proposta. Décadas de investigação realizada a bordo do $J R$ permitem que as operações de perfuração sejam rotineiras e ao mesmo tempo estimulantes - rotineiras, porque os mesmos processos já foram realizados anteriormente muitas vezes, e estimulantes porque os cientistas e técnicos nunca sabem o que realmente será encontrado em cada expedição (http://joidesresolution.org/node/2825).

Cada expedição a bordo do $J R$ normalmente dura dois meses. Os cientistas, técnicos e tripulação trabalham em turnos de 12 horas. Durante os chamados períodos de trânsito até aos locais de perfuração, todos se preparam para as atividades e operações de perfuração que em breve decorrerão ao longo das 24 horas do dia. Quando o $J R$ chega ao local designado, a equipe que trabalha na plataforma de perfuração une pacientemente seções de tubos de aço, com 10 metros de comprimento, umas às outras. A tubagem é depois levantada por um guindaste com $62 \mathrm{~m}$ de altura, e enviada para o fundo do mar em séries de tubos que podem atingir mais de $9.100 \mathrm{~m}$ de comprimento (Fig. 3). Na extremidade da tubagem de perfuração é acoplada uma broca que gira velozmente através de sedimentos e rochas e permite recolher testemunhos desses materiais. Se tudo correr bem, os testemunhos são então trazidos para cima, recuperados a partir do interior dos tubos, e o processo é repetido tantas vezes quanto for necessário. 


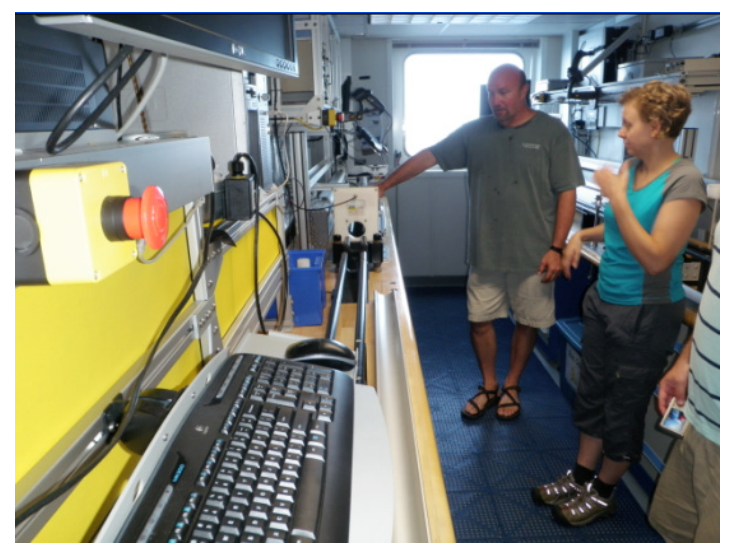

Figure 4. Scientist and teacher examining gamma ray instruments aboard the JOIDES Resolution.

Figura 4. Cientista e professora examinam instrumentos de raios gama a bordo do navio JOIDES Resolution.

When the announcement, "Core on deck!", is made, scientists stop whatever they are doing to gather on the "catwalk" as the core is removed from the drilling string. Samples are taken systematically by the scientists, who then go to their onboard laboratories to extract as much information as they can (http://joidesresolution.org/node/2825). Some specialists explore the igneous and metamorphic petrology, inorganic geochemistry, paleomagnetics, structural geology, and physical properties of the core materials (Fig. 4). Other specialists examine microscopic fossils to determine the age of the materials as nearly as possible. (See Terra Didatica, v. 7, no. 1, to learn more about these foraminifera, radiolarian, coccolithophoridae, and other nanofossils.)

Before the drill pipes are finally removed from the core hole, the crew sends down an array of geophysical instruments to obtain geophysical measurements of the sediments and rocks. Supervising this phase of the project is a logger from the Borehole Research Group at the Lamont-Doherty Earth Observatory of Columbia University (http:// www.ldeo.columbia.edu/BRG/.) Downhole logging provides much additional valuable information about the sediments and rocks beneath the oceans.

\section{Ocean Drilling and Education}

Since 2005, teachers have been able to join the scientists aboard the JR to create educational resources for students and the general public. Education opportunities and materials are coordinated
Quando se ouve o anúncio "Core on Deck!", os cientistas param o que estão a fazer e reúnem-se no passadiço ("catwalk") para assistir à recuperação do testemunho da tubagem de perfuração. As amostras são constantemente recolhidas pelos cientistas, que, em seguida, vão para os seus laboratórios de modo a obter o máximo de informações possível ainda a bordo doJR (http://joidesresolution.org/node/2825). Nos vários laboratórios que existem no $J R$ há cientistas que investigam a petrologia ígnea e metamórfica, a geoquímica inorgânica, o paleomagnetismo, a geologia estrutural e as propriedades físicas dos materiais recolhidos (Fig. 4). Além destes, existem ainda paleontólogos que analisam os fósseis microscópicos preservados nos materiais recolhidos para determinar a sua idade aproximada (leia o n. ${ }^{\circ} 1$ do vol. 7 de Terra Didatica para aprender mais sobre este tipo de fósseis, tais como os foraminíferos, os radiolários, ou os cocolitoforídeos e outros nanofósseis).

Antes da tubagem usada nas operações de perfuração ser finalmente removida do furo, a tripulação envia uma série de instrumentos geofísicos ao longo dos tubos para obter medições de algumas propriedades dos sedimentos e rochas. A supervisão desta fase das operações é feita por um técnico de registo do perfil geofísico do furo oriundo do Borehole Research Group do LDEO da Universidade de Columbia (http://www.ldeo.columbia.edu/BRG/). O registo do perfil geofísico ao longo do furo proporciona a obtenção de informações adicionais e valiosas sobre as rochas e os sedimentos localizados abaixo do fundo do mar.

\section{Perfuração científica do oceano e Educação}

Desde 2005 vários professores tiveram a oportunidade de, em colaboração com os cientistas a bordo do $J R$, produzir recursos educativos destinados a estudantes e ao público em geral. As atividades de formação profissional destinadas aos professores e o desenvolvimento dos materiais educativos são coordenados pela Deep Earth Academy of the Consortium for Ocean Leadership (http://www.oceanleadership.org/education/deep-earth-academy/).

Em quatro ocasiões, aproveitando períodos de trânsito realizados pelo $J R$ entre expedições, a Deep Earth Academy proporcionou condições para que grupos de professores pudessem viajar no $J R$ para aprender, em primeira mão, sobre as operações e as descobertas científicas realizadas a bordo do navio. Estes eventos são designados "School of Rock". Quando o $J R$ esteve em doca seca para ser remode- 
by the Deep Earth Academy of the Consortium for Ocean Leadership (http://www.oceanleadership. org/education/deep-earth-academy/).

On five occasions as the JR sailed between expeditions, Deep Earth Academy arranged for groups of teachers to travel aboard to learn about the scientific operations and discoveries. These are called the "Schools of Rock." When the JR was in drydock for refit, two Schools of Rock were held at Texas A \& M University, home of the Gulf Coast Repository, where thousands of cores taken during the DSDP, ODP, and IODP are permanently archived (http://iodp.tamu.edu/curation/gcr/.)

Teachers aboard the ship and at the Gulf Coast Repository Schools of Rock have cooperated with research scientists and Deep Earth Academy educational specialists to create dozens of activities, posters, and other resources that have been used in classrooms and at public science festivals. These are available at http://www.oceanleadership. org/education/deep-earth-academy/educators/ classroom-activities/.

One example of an activity that highlights the scientific discoveries made through ocean drilling is "Nannofossils Reveal Seafloor Spreading Truth" (http://www.oceanleadership.org/education/deep-earth-academy/educators/classroom-activities/ grades-5-8/nannofossils-reveal-seafloor-spreading-truth/). Students plot data from the ten sites on either side of the Mid-Atlantic ridge to see the evidence which proved that the age of the ocean floor increased regularly with distance from the ridge axis.

Another example teaches the value of data obtained by borehole logging techniques, "It's Not Just the Core that Tells the Hole Story" (http://www.oceanleadership.org/education/deep-earth-academy/educators/classroom-activities/ grades-9-12/its-not-just-the-core-that-tells-the-story/).

As this is written, three classroom teachers from France, England, and the United States are serving as "Education Officers" for the current JR expedition, Leg 345. (http://joidesresolution. org/node/2738). They are blogging in English and French about the activities aboard the ship, and will create educational materials. Through the efforts of the Education Officers, the scientific discoveries become more accessible to students and the public.

During Expedition 339, Hélder Pereira of the Escola Secundária de Loulé, Portugal, served as Education Officer. He described discoveries about lado e modernizado foram realizadas duas "School of Rock" na Universidade de Texas A \& $M$, na qual está situado o Gulf Coast Repository, onde milhares de testemunhos recolhidos durante o DSDP, ODP, e IODP são arquivados de modo permanente (http:// iodp.tamu.edu/curation/gcr/).

Os professores que tiveram a oportunidade de navegar a bordo do navio e que participaram nas "School of Rock", realizadas no Gulf Coast Repository, têm cooperado com cientistas e especialistas em educação da Deep Earth Academy para criar dezenas de atividades, cartazes e outros recursos que têm sido usados em salas de aula e em festivais de ciência. Estes recursos educativos estão disponíveis em http://www.oceanleadership.org/education/deep-earth-academy/educators/classroom-activities/.

Um exemplo de atividade que evidencia as descobertas científicas feitas por intermédio da realização de perfurações oceânicas intitula-se "Nannofossils Reveal Seafloor Spreading Truth" (http://www. oceanleadership.org/education/deep-earth-academy/educators/classroom-activities/grades-5-8/ nannofossils-reveal-seafloor-spreading-truth/). Para realizar a atividade os estudantes têm que usar dados relativos aos furos realizados na Leg 3 do DSDP, em ambos lados da Dorsal Média-Atlântica no Atlântico Sul, que permitem demonstrar que a idade do fundo do oceano aumenta regularmente com a distância ao eixo da dorsal.

Outro exemplo mostra o valor dos dados obtidos pelos métodos que permitem efectuar medições geofísicas ao longo dos furos "It's Not Just the Core that Tells the Hole Story" (http://www.oceanleadership.org/education/deep-earth-academy/ educators/classroom-activities/grades-9-12/its-not-just-the-core-that-tells-the-story/).

Enquanto escrevemos este artigo três professores oriundos de França, Inglaterra e Estados Unidos da América estão a bordo do $J R$ servindo como Assessores para a Educação da Expedição 345 (http://joidesresolution.org/node/2738). Eles estão a escrever blogues em Inglês e Francês sobre as atividades realizadas a bordo do navio, e desenvolverão materiais educativos. Por meio do esforço e determinação dos Assessores para a Educação as descobertas científicas realizadas a bordo do $J R$ têm-se tornado mais acessíveis aos estudantes e ao público em geral.

Hélder Pereira, da Escola Secundária de Loulé, Portugal, serviu como Assessor para a Educação durante a Expedição 339. Por meio de blogues, publicados em Inglês e Português, na página web da expedição (http://joidesresolution.org/node/2053) 
the Mediterranean Outflow Waters and the connection between the Atlantic and Mediterranean through blogs posted in English and Portuguese (http://joidesresolution.org/node/2053) on the Expedition's website. He has also developed many educational materials based on ocean drilling which are provided below.

\section{Conclusion}

The addition of Brazil as a member nation of the Integrated Ocean Drilling Program will provide many scientific and educational opportunities based on ocean drilling. In addition to the information and online resources suggested in this article, Brazilian scientists, students, and teachers can learn from what has already been discovered by accessing publications and drilling data (http://www. oceanleadership.org/wp-content/uploads/2009/02/ AccessingDrillingDataPubs4_10.pdf).

\section{References/Resources}

The list below was suggested by Hélder Pereira (Escola Secundária de Loulé, Portugal).

Expedition 339: Mediterranean Outflow webpage http://joidesresolution.org/node/2053 and blog http://joidesresolution.org/blog/52

O estudo dos fundos oceânicos - Parte I URL: http:// www.es-loule.edu.pt/biogeo/sor2009/O_estudo dos fundos oceanicos Parte I.pdf.

O estudo dos fundos oceânicos - Parte II URL: http:// www.es-loule.edu.pt/biogeo/sor2009/O estudo_dos_fundos_oceanicos_Parte_II.pdf.

Presentation for the International Year of the Planet Earth (2007-2009): URL: http://www.es-loule. edu.pt/biogeo/sor2009/IODP@IYPE LisbonEvent09.pdf, URL: http://www.es-loule. edu.pt/biogeo/sor2009/SOR@IYPE_LisbonEvent09.pdf

Presentation about microfossils: URL: http://www. es-loule.edu.pt/biogeo/sor2009/Microfosseis os contadores de historias dos oceanos.pd $\bar{f}$

Projecto LABoratório Oceano (LABO) website (many resources about the study of the ocean): URL: http://www.es-loule.edu.pt/cfp/moodle/course/ view.php?id=17

Videos from the JOIDES Resolution: URL: http:// joidesresolution.org/node/2110. ele descreveu as descobertas efetuadas sobre o escoamento da Água Mediterrânica em direção ao Atlântico e a ligação entre o Oceano Atlântico e o Mar Mediterrâneo. Ele desenvolveu ainda vários materiais e atividades educativas baseadas na perfuração científica do oceano que estão indicados abaixo.

\section{Conclusão}

A adesão do Brasil ao Integrated Ocean Drilling Program (IODP) proporcionará muitas oportunidades científicas e educativas relacionadas com a perfuração do oceano. Para além das informações e recursos referidos neste artigo, os cientistas, estudantes e professores brasileiros podem aprender e ensinar aquilo que já foi descoberto, no âmbito dos vários programas científicos de perfuração oceânica, acedendo às publicações e dados disponíveis on-line (http://www.oceanleadership.org/wp-content/uploads/2009/02/AccessingDrillingDataPubs4_10.pdf).

\section{Referências/Recursos}

Recursos educativos sugeridos por Hélder Pereira (Escola Secundária de Loulé, Portugal)

Apresentações sobre o IODP e a "School of Rock" 2009 efectuadas durante o Ano Internacional do Planeta Terra (2007-2009) . URL: http://www.es-loule. edu.pt/biogeo/sor2009/IODP@IYPE LisbonEvent09.pdf

Apresentação sobre microfósseis. URL: http://www. es-loule.edu.pt/biogeo/sor2009/Microfosseis os_contadores_de_historias_dos_oceanos.pdf http://www.es-loule.edü.pt/biogeo/sor2009/SOR@ IYPE LisbonEvent09.pdf

O estudo dos fundos oceânicos - Parte I. URL: http:// www.es-loule.edu.pt/biogeo/sor2009/O estudo_dos_fundos_oceanicos_Parte_I.pdf

O estudo dos fundos oceânicos - Parte II. URL: http:// www.es-loule.edu.pt/biogeo/sor2009/O_estudo_dos_fundos_oceanicos_Parte_II.pdf

Página web da Expedição 339: Mediterranean Outflow. URL: http://joidesresolution.org/node/2053 e respectivo blogue. URL: http://joidesresolution.org/blog/52

Projecto LABoratório Oceano (LABO) (sítio com muitos recursos sobre o estudo do oceano). URL: http://www.es-loule.edu.pt/cfp/moodle/course/ view.php?id $=17$

Vídeo "Core on Deck! The Journey of how the Samples travel from the Rig Floor to the Core Lab". URL: http://www.youtube.com/ watch?v=wC91DPvvze0 